\title{
EFFECT OF PROTEIN AND CHROMIUM INTAKE ON SOME NUTRITIONAL AND BIOCHEMICAL STATUS IN DIABETIC RATS
}

\author{
by \\ Soheir Ahamed Al-Masri \\ Food Sciences and Nutrition Dep, Faculty of Food Sciences and \\ Agriculture, King Saud University, Riyadh, Saud Arabia
}

Research Gournal Specific Education

Faculty of Specific Education

Mansoura University

ISSUE NO. 18, SEP. 2010

مجلة بحوث التربية النوعية - جامعة المنصورة

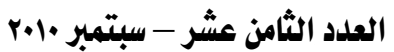




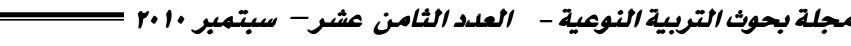 \\ EFFECT OF PROTEIN AND CHROMIUM INTAKE ON SOME NUTRITIONAL AND BIOCHEMICAL STATUS IN DIABETIC RATS
}

\author{
Soheir Ahamed Al-Masri*
}

\section{ABSTRACT}

The present study was designed to investigate the effects of protein and chromium intake on some nutritional and biological status in streptozotocin induced diabetic rats. This study was conducted on forty -nine Sprague -Dawley adult male rats, weighting $190 \pm 15 \mathrm{~g}$ were classified into control and six treated groups with drug, chromium, high protein, low protein, high protein with chromium and low protein with chromium groups for ten weeks.

The obtained results revealed that the drug, chromium, high protein, high protein with chromium and low protein with chromium groups rat group had a significant higher values of body weight gain, feed efficiency ratio, insulin, hemoglobin, packed cell volume, GPX, SOD and globulin and a significant lower value in ALT, AST, AP, $\gamma$ GT , creatinine and urea when compared with control group but a significant decrease in the value of glucose and MDA compared with drug group .

The high protein and high protein with chromium rat groups showed a significant increase in the value of total protein but high protein with chromium and low protein with chromium rat groups showed significant decrease in the value of albumin/globulin ratio when compared with control group or with drug rat group.

The chromium, high protein, high protein with chromium and low protein with chromium rat groups showed significant decrease in the value of total bilirubin while the chromium, low protein and low protein with chromium rat groups showed significant decrease in the value of uric acid when compared with control group.

The low protein rat group showed a non significant difference in final weight, weight gain, feed intake, feed efficiency ratio, insulin, packed cell volume, SOD , MDA, ALT, AST, AP , $\gamma$ GT, total bilirubin and creatinine and a significant decrease in glucose and GPX but a significant increase in heamoglobin and globulin when compared with control group but showed a significant decrease in weight gain, feed efficiency ratio, insulin, packed cell volume, GPX, SOD and a significant increase in glucose, MDA, ALT, AST, AP , $\gamma$ GT and creatinine when compared with drug group.

Key wards :( protein - chromium - diabetic rat).

"Food Sciences and Nutrition Dep, Faculty of Food Sciences and Agriculture, King Saud University, Riyadh, Saud Arabia 


\section{أثر تناول البروتين والكروهيوم على الهالة الغذائية والبيوكيميائية في الفئران الإبة بالداء السكري \\ سهـيـر احهـد الهصريث}

\section{المنص العربي}

تهـدف هـذه الدراسـة إلى تقـدير اثر تنـاول البروتين و الكروميوم على الحـالـة الغذائيسة والبيولوجيـة

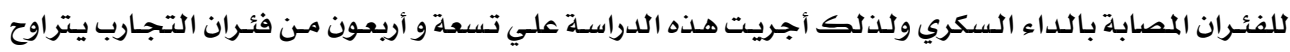

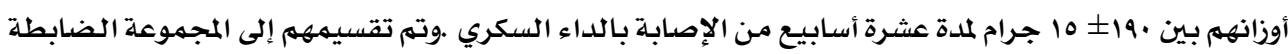

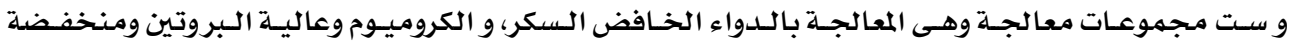

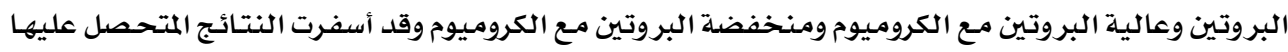

فيما يلي:

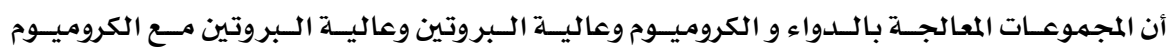

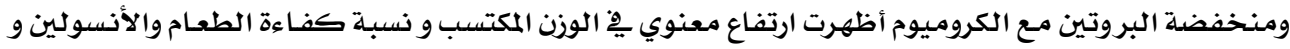
ALT, AST, AP, رGT والجلوبيـولين وانخفاض معنسوي و

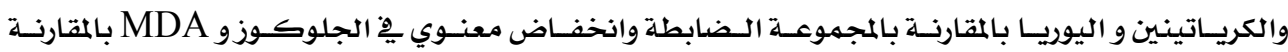

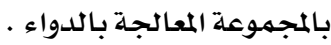

أن مجموعتي عالية البروتين وعالية البروتين مـع الكروميوم أظهرت ارتفاع معنوي ِِّ البروتين الكلي

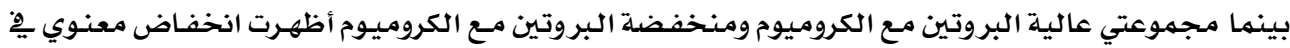

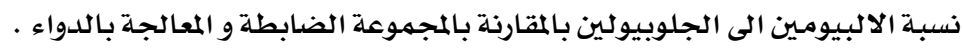

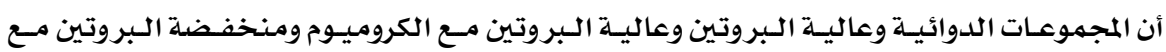

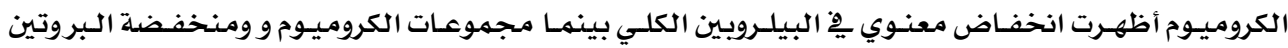
ومنخفضة البروتين مـع الكروميوم أظهرت انخفاض معنوي ِِّ حمض اليوريك بالمقارنة بالمجموعة الضـابطة.

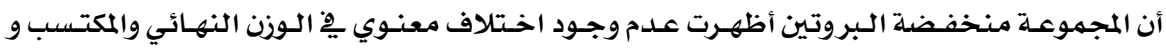

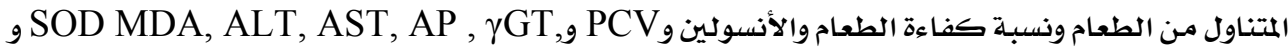

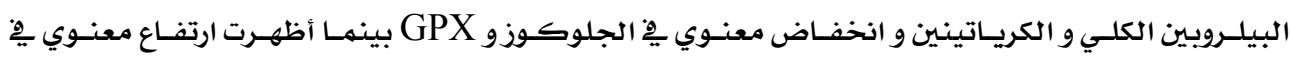

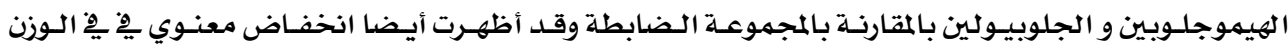

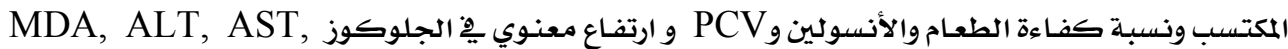

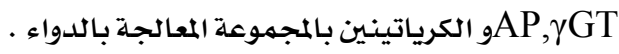

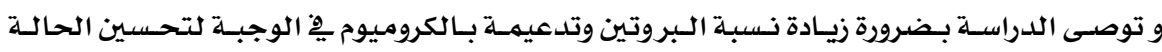

الصحية لمرضى الداء السكري الدواء بلدي

قسم علوم الأغذية و التغذية - كلية علوم الأغذية و الزراعة -جامعة الملك سعود- المملكة العربية السعودية 


\title{
EFFECT OF PROTEIN AND CHROMIUM INTAKE ON SOME NUTRITIONAL AND BIOCHEMICAL STATUS IN DIABETIC RATS
}

\author{
Soheir Ahamed Al-Masri*
}

\section{INTRODUCTION}

Diabetes mellitus is a metabolic disease characterized by hyperglycemia resulting from defects in insulin secretion, insulin action, or both. There are two important characteristics of this disease, one is insulin resistance, which means the failure of peripheral tissues such as liver, muscle and adipose tissue to respond to physiologic doses of insulin, and the other one is dysfunction of pancreatic beta cell to properly secrete insulin in response to elevated blood glucose level (Wattanakit et al., 2005 and Ziegler, 2005).

Protein is certainly an essential nutrient which plays many key roles in the way our bodies function (Hoffman and Flavo 2004). Proteins are the natural choice of the body when faced with diabetes. In uncontrolled diabetes, muscle protein is broken down into amino acids to be converted into glucose by the liver. Since proteins have to supply enough energy to substitute for carbohydrates, proteins are broken down faster than they are made. Excess protein has been linked with osteoporosis, kidney disease, calcium stones in the urinary tract, and some cancers. Low-protein diets ameliorate the symptoms of some diabetic patients, possibly by improving insulin sensitivity and alleviating hyperinsulinemia (Rigalleau et al., 1998). The excess of amino acids attenuates insulin-stimulated glucose transport in vitro, while amino acid deficiency enhances it (Takano et al., 2001 and Tremblay and Marette 2001). In addition, dietary protein has been shown to modulate some insulin-dependent processes, such as the regulation of enzymes for gluconeogenesis (Rossetti et al., 1989) .

Dietary supplements are widely used not only by the general public but also by diabetic patients. The adequate intake of foods rich in chromium should be considered as part of the nutritional to diabetic patients. Chromium is an essential trace element typically found in foods, such as egg yolks, coffee, green beans, nuts, and whole-grain products. Chromium assists in weight loss, proper insulin functioning, and blood sugar

*Food Sciences and Nutrition Dep, Faculty of Food Sciences and Agriculture, King Saud University, Riyadh, Saud Arabia 
regulation. It may also help decrease appetite and sugar cravings, increase muscle mass, regulate cholesterol, and help break down carbohydrates, fats, and protein (Kalman, 2003)

Chromium is required for the maintenance of normal glucose and fat metabolism and used for the treatment of diabetes and high blood sugar levels. Additionally, it may also help regulate blood sugar levels in patients with low blood sugar disorders. Chromium is the glucose tolerance factor which potentiates the action of insulin and energetic metabolism, without serious adverse effects (Cefalu and $\mathrm{Hu} 2004$ and Fernando and Martha 2005).

People with diabetes are frequently given advice about protein and chromium that has no scientific basis and need adequate and accurate information about protein on which to base their food decisions. The present study was designed to investigate the effect of the protein either low or high with or without chromium on the nutritional and some biochemical parameters on streptozotocin induced diabetic rats.

\section{MATERIALS AND METHODS}

\section{A - Materials:}

\section{1-Streptozotocin:}

Streptozotocin is procured from Sigma, St. Louis, MO, USA. It is often used for preparing type 1 diabetes animal model because of its differential wreck action to beta cells of pancreas. It can also be used for preparing non-insulin dependent diabetes animal model (Alain et al., 1969 and Arulmozhi et al., 2004).

\section{2- Antidiabetic drug:}

Amaryl drug is produced by Saofi -Avents Egypt under licence of Saofi-Avents Germany. It is antidiabetic sulfonylurea. Each tablet contains $2 \mathrm{mg}$ glimepiride. The human therapeutic dose is $4 \mathrm{mg}$ daily. The human therapeutic dose was converted to rat dose according to Paget and Barnes, (1964) that was $0.36 \mathrm{mg} / \mathrm{kg}$ body weight daily which dissolved in distilled water and given to rats by oral intubation.

\section{3-Chromium drug:}

Chromium drug is produced by Arab Company for Pharmaceuticals and Medicinal Plants (MEPACO) Egypt. Each capsule contains $200 \mathrm{mcg}$ 


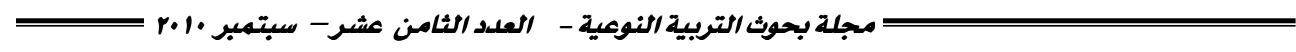

chromium picolinate. The human therapeutic dose of chromium is $400 \mathrm{mcg}$ daily. The human therapeutic dose was converted to rat dose according to Paget and Barnes, (1964) that was $36 \mathrm{mcg} / 100 \mathrm{~g}$ body weights daily which dissolved in distilled water and given to rats by oral intubation.

\section{3- Protein:}

High protein and low protein diet was prepared by $\pm 50 \%$ the normal level of casein in standard diet.

\section{4-Experimental animals:}

A total of forty-nine Sprague -Dawley adult male rats were purchased from the Agricultural Research Center, Giza, Egypt. The average weight was $190 \pm 15 \mathrm{~g}$. The animals were kept under observation for five days before experiment and supplied with standard diet and water ad libitum. The standard diet comprised of casein $(200 \mathrm{~g} / \mathrm{kg})$, corn starch $(497 \mathrm{~g} / \mathrm{kg})$, sucrose $(100 \mathrm{~g} / \mathrm{kg})$, cellulose $(30 \mathrm{~g} / \mathrm{kg})$, corn oil $(50 \mathrm{~g} / \mathrm{kg})$, mineral mixture $(100 \mathrm{~g} / \mathrm{kg})$, vitamin mixture $(20 \mathrm{~g} / \mathrm{kg})$ and DL-methionine $(3 \mathrm{~g} / \mathrm{kg})$. The standard diet was performed according to NRC (1995).

\section{B-Methods:}

The rats were randomly divided into seven groups (7 rats /group). The rats were injected with a single intraperitoneal dose of streptozotocin $(55 \mathrm{mg} / \mathrm{kg}$ body weight) in $0.1 \mathrm{M}$ citrate buffer of $\mathrm{pH} 4.5$ then supplied with $5 \%$ glucose solution for $48 \mathrm{~h}$ after injection in order to prevent hypoglycemia (Peschke et al .,2000). After four days, blood samples were taken from orbital plexus for estimation of glucose. The rats having persistent hyperglycemia were considered as diabetic rats and used for the experiment. The diabetic rats were classified into control and treated six groups with drug, chromium, high protein, low protein, high protein with chromium and low protein with chromium groups. The feed intake was calculated daily and the body weight gain was recorded weekly. At the end of the experiment (ten weeks), the rats were fasted overnight then sacrificed to obtain blood samples.

First part of blood was heparenized for estimation of hemoglobin and packed cell volume (PCV) (Drabkin, 1949 and Mc Inory 1954). Second part of blood was collected in tubes containing potassium oxalate and sodium fluoride for the estimation of glucose by $O$-toluidine method (Sasaki et al., 1972). Third part of blood was left to coagulate then centrifuged at 
$3000 \mathrm{rpm}$ for 15 minutes to obtain serum. Serum insulin, alanine and aspartate aminotransferase (ALT\&AST), alkaline (AP) and gamma glutamyl phosphate $(\gamma$ GT) activity were estimated according to Wilson and Miles (1977), Reitman and Frankel (1957), Kind and King (1954) and Henry, (1974), respectively. In addition, total protein, albumin, total bilirubin, creatinine, urea and uric acid were estimated according to Weichselbaum (1946) and Bartholomev and Delany (1966) ,Jendrassik (1938) ,Bonsens and Taussky,(1984), Patton and Crouch , (1977) and Fossati et al., (1980), respectively. Liver Glutathione peroxidase(GPX) , superoxide dismutase (SOD) and malondialdehyde (MDA) activity was determined as described by the method of Beutler et al., (1963), Dechatelet et al. (1974) and Stocks and Donnandy (1971), respectively.

Calculation of some parameters was occurred as following:

* Feed efficiency ratio $(\mathrm{FER})=$ weight gain $(\mathrm{g}) /$ feed intake $(\mathrm{g})$ (Chapman et al., 1950).

*Serum globulin $(\mathrm{G})=$ total proteins- albumin $($ Coles, 1974).

*A/G ratio $=$ albumin / globulin values for each individual sample .

\section{C-Statistical analysis:}

All the obtained data were statistically analyzed by SPSS computer soft ware. The calculated occurred by analysis of variance ANOVA and follow up test LSD (Artimage and Berry 1987).

\section{RESULTS}

\section{1-Nutritional results:}

The statistical date in table (1) denoted that, the drug, chromium, high protein, low protein, high protein with chromium and low protein with chromium rat groups had a significant higher values of body weight gain and feed efficiency ratio $(p<0.01)$ when compared with control group.

The chromium, high protein, high protein with chromium and low protein with chromium rat groups showed non significant difference in final body weight, weight gain, feed intake and feed efficiency ratio in compared with drug rat group. The low protein rat group showed a significant decrease in weight gain and feed efficiency ratio in compared with drug rat group. 


\section{3-Biochemical results:}

Data presented in table (2) showed that the value of glucose was significantly decreased at $\mathrm{p}<0.001$ in drug, chromium, high protein, high protein with chromium and low protein with chromium rat groups and at $\mathrm{p}$ $<0.05$ in low protein rat group when compared with control group. The value of insulin was significantly increased at $p<0.001$ in drug, chromium, high protein and high protein with chromium rat groups and at $p<0.01$ in low protein with chromium rat group when compared with control group. The mean value of hemoglobin and packed cell volume was significantly increased at $\mathrm{p}<0.01$ in drug, chromium, high protein, high protein with chromium rat groups and low protein with chromium when compared with control group. The low protein rat group showed significant increase in hemoglobin at $\mathrm{p}<0.05$ in when compared with control group.

The chromium, high protein, high protein with chromium and low protein with chromium rat groups showed non significant difference in in the mean value of glucose, insulin, hemoglobin and packed cell volume compared with drug rat group. The low protein rat group showed a significant increase in glucose and a significant decrease in insulin, packed cell volume compared with drug rat group.

Data in table (3) revealed that the value of GPX was significantly increased at $p<0.001$ in drug, chromium, high protein, high protein with chromium and low protein with chromium rat groups but significant decrease at $\mathrm{p}<0.05$ in low protein rat group when compared with control group. The value of SOD was significantly increased at $p<0.001$ in chromium and high protein with chromium rat group and at $\mathrm{p}<0.01$ in drug, high protein, and low protein with chromium rat groups when compared with control group. The value of MDA was significantly decreased at $p$ $<0.001$ in chromium, high protein, high protein with chromium and low protein with chromium rat groups and at $\mathrm{p}<0.01$ in drug rat group when compared with control group.

The low protein rat group showed a significant decrease in GPX and SOD but significant increase in MDA compared with drug rat group.

Data recorded in table (4) showed that the values of ALT and $\gamma$ GT were significantly increased at $\mathrm{p}<0.001$ in drug and high protein with chromium rat groups and at $\mathrm{p}<0.01$ in chromium, high protein and low protein with chromium rat groups when compared with control group. The 
value of AST was significantly decreased at $p<0.001$ in drug, chromium, high protein, high protein with chromium rat groups and at $p<0.01$ in low protein with chromium rat group when compared with control group. The value of AP was significantly decreased at $p<0.01$ in at chromium, high protein, high protein with chromium and low protein with chromium rat groups and at $\mathrm{p}<0.05$ in drug when compared with control group.

The low protein rat group showed a non significant difference in ALT, AST, AP and $\gamma$ GT compared with control rat group but significant increase compared with drug rat group.

From the data in table (5), it could be observed that the value of total protein was significantly increased in high protein and high protein with chromium rat groups at $\mathrm{p}<0.05$ while the value of globulin was significantly increased at $\mathrm{p}<0.001$ in high protein with chromium rat group and at $\mathrm{p}<0.01$ in drug, chromium, high protein, and low protein with chromium rat groups but at $\mathrm{p}<0.05$ in low protein rat group when compared with control group. The value of albumin/ globulin ratio was significantly decreased at $\mathrm{p}<0.05$ in high protein with chromium and low protein with chromium rat groups when compared with control group.

The value of total protein was significantly increased in high protein and high protein with chromium rat groups while the value of albumin/ globulin ratio was significantly decreased in high protein with chromium and low protein with chromium rat groups compared with drug rat group.

The data in table (6), it could be observed that the value of total bilirubin was significantly decreased in chromium, high protein, high protein with chromium and low protein with chromium rat groups at $\mathrm{p}<0.01$ while the value of creatinine was significantly decreased at $p<0.01$ in drug, chromium, high protein rat groups and at $\mathrm{p}<0.05$ in high protein with chromium and low protein with chromium rat groups when compared with control group. The value of urea was significantly decreased in drug, chromium, high protein, low protein ,high protein with chromium and low protein with chromium rat groups at $\mathrm{p}<0.01$ while the value of uric acid was significantly decreased in chromium, low protein and low protein with chromium rat groups at $\mathrm{p}<0.05$ when compared with control group.

The values of total bilirubin, creatinine, urea and uric acid were in non significant difference in chromium, high protein, low protein, high protein with chromium and low protein with chromium rat groups except 
creatinine in low protein rat group which showed significant increase when compared with drug rat group.

\section{DISCUSSION}

Pathological alterations in non-enzymatic glycosylation of proteins and lipids can interfere with their normal function, cellular protein kinase $\mathrm{C}$ activation and oxidative stress in diabetic animal and human. Hyperglycemia depletes natural anti-oxidants and facilitates the production of free radicals (Abd El Ghany, and Khaled, 2000 and Johansen et al., 2005).

It is well known that streptozotocin induced diabetes is linked to the production of reactive nitrogen species and oxygen species which damages DNA of pancreatic cells, leading to cell necrosis and loss of insulin Streptozotocin diabetic rats groups showed loss in body weight resulting of protein wasting due to unavailability of carbohydrate for utilization as an energy source (Szkudelski, 2001). Gastroparesis is a form of diabetic neuropathy that can affect the digestion of food and retard glucose absorption. Symptoms of gastropathy can include earlysatiety, decreased appetite, bloating, abdominal discomfort, nausea, vomiting and unexplained hypo/hyperglycemia. Gastropathy can result in postprandial hypoglycemia that is later followed by higher than normal blood glucose rises (Valentine et al .,1998).

The reduction in hemoglobin and packed cell volume may be attributed to an increasing glycation of a number of proteins including hemoglobin. Glycated hemoglobin is considered as one of the markers of degree of oxidative stress in diabetes mellitus (Whiteside, 2005). Streptozotocin molecules might increase the production of oxygen free radicals that play a crucial role in determining tissue injury as exert direct or indirect effects on islet endothelium and mediate fragmentation of nuclear DNA in beta cells (Hui et al .,2007). Persons with diabetes are several times more prone to kidney disease than the general population. Hyperglycemia is the primary risk factor associated with development of both micro- and macrovascular complications. Hyperglycemia produces its deleterious effects is the production of free reactive oxygen species (ROS). Thus, oxidative stress, defined as a persistent imbalance between the excessive production of ROS and/or defects in antioxidant defense. The mitochondrial process involved in the glucose-mediated insulin secretion is particularly 
affected by oxidative stress. Increase in mitochondrial ROS, a consequence of increased glucose levels (American Diabetes Association, 2004).

Sulphonylurea drug is known to lower the blood glucose level by stimulating B-cells to release insulin (Bethesda 2001).

Current evidence indicates people with diabetes have similar protein requirements to those of the general population. Although protein plays a role in stimulating insulin secretion, excessive intake should be avoided as it may contribute to the pathogenesis of diabetic nephropathy (Brenneret al., 1982 and Franz, 1997). Restricting protein intake to less than requirements has no additional benefit on the progression of renal disease and may result in inadequate intake of essential amino acids. However, there is some evidence that the use of non-meat protein sources may be preferable to animal protein sources in the management of renal disease (Pedrini et al., 1996).

Protein nutrition influences the signaling pathway of insulin. Upon activation by insulin, the insulin receptor (IR) binds to various types of substrate proteins, including adapters, docking proteins and enzymes; the family of IR substrate (IRS) proteins constitutes the major group (White 2002). Dietary protein is a very strong regulator of serine phosphorylation of IRS-1 in muscle. This change is accompanied by an increased sensitivity of IRS-1 to insulin. This increase may contribute to elevated insulin responsiveness by manipulations of dietary protein (Toyoshima et al., 2004).

The low protein rats gained weight at a considerably lower rate than normal. This was obtained in the absence of any decrease of spontaneous food intake but basal plasma insulin levels were decreased by $40 \%$ in low protein rats than normal. The basal hepatic glucose production in the low protein rats was similar to that in the normal rats. The modest improvement of glucose tolerance which is revealed in the low protein rats results from changes in the insulin action upon the target tissues because both the insulin-mediated glucose uptake by peripheral tissues and the ability of insulin to suppress hepatic glucose output are enhanced (Swenne et al ., 1988 and Crace et al .,1990).

Hyperuricemia can be the consequence of increased uric acid production or decreased excretion. Any cause for decreased glomerular filtration, tubular excretion or increased reabsorption would result in an 


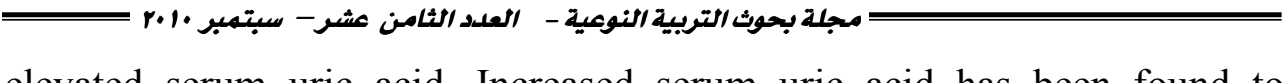

elevated serum uric acid. Increased serum uric acid has been found to predict the development of renal insufficiency in individuals with normal renal function (Schmidt-Nielsen et al., 1985). High fat and high protein food may also cause increased oxidative stress in diabetes, resulting in further injury to pancreatic cells.

Chromium deficiency can result in decreased glucose tolerance but is believed to be rare. Chromium picolinate significantly improved glycemic control in people with diabetes (Anderson, 1997 and Albarracin et al., 2008). Chromium improves the action of insulin by improving tyrosine kinase activity on the insulin receptor. Tyrosine kinase, the enzyme required for phosphorylation, is chromium dependent, and phosphotyrosine phosphatase, an enzyme that inactivates the insulin receptor, is inhibited by chromium. Chromium exerts a powerful cellular antioxidant action and decreases the hepatic extraction of plasma insulin (Davis et al., 1997 and Anderson et al., 2001). 


\section{REFERENCE}

Abd El Ghany, M.A and Khaled, A. S. (2000): Effect of nutritional status of diabetic elderly on their healthy pattern $.6^{\text {th }}$ Scientific Conference of Home Economics, Helwan Univ.23-24 April 86-101.

Alain, J., Andre, E.L, Werner, S and Albert, E.R.(1969): Diabetogenic action of streptozotocin: Relationship of dose to metabolic response. J Clin Invest , 48: 2129-2130.

Albarracin, C.A , Fuqua, B.C, Evans, J.L and Goldfine, I.D (2008): Chromium picolinate and biotin combination improves glucose metabolism in treated, uncontrolled overweight to obese patients with type 2 diabetes. Diabetes Metab Res Rev. Jan-Feb;24(1):41-51.

American Diabetes Association (2004): Nutrition principles and recommendations in diabetes. Diabetes Care; 27:S36-S46.

Anderson, R.A, Cheng, N and Bryden, N.A (1997): Elevated intakes of supplemental chromium improve glucose and insulin variables in individuals with type 2 diabetes. Diabetes. 46:1786-1791.

Anderson, R.A., Roussel, A.M., Zouarei,N., Mahjoub, S .,Matheau, J.M and Kerkeni, A.(2001): Potential antioxidant effects of zinc and chromium supplementation in people with type 2 diabetes mellitus. J Am Coll Nutr; 20:212-218.

Artimage G.Y and Berry W.G (1987): Statistical Methods 7th Ed. Ames, Iowa Stata University Press, 39-63.

Arulmozhi, D.K., Veeranjaneyulu, A and Bodhankar, S.L.(2004): Neonatal streptozotocin-induced rat model of Type 2 diabetes mellitus: A glance. Indian J Pharmacol; 36: 217-221.

Bartholomev, R.J and Delaney, A. (1966): Proc Aust. Assoc .Biochemists .1, 214.

Bethesda, M.D. (2001): AHFS Drug Information, American Society of HealthSystem Pharmacists, p. 3008 and 3049.

Beutler, E., Duron, O. and Kelly, B. (1963): Improved method for the determination of blood glutathione. J. Lab. Clin. Med., 61: 882-890.

Bonsens, K. E. and Taussky, D. H. (1984): Determination of serum creatinine J Ch Inv 27, 648-660.

Brenner, B.M, Meyer, T.W and Hostetter, T.H. (1982): Dietary protein intake and the progressive nature of kidney disease: the role of hemodynamically mediated glomerular injury in the pathogenesis of progressive glomerular sclerosis in aging, renal ablation and intrinsic renal disease. N Engl J Med.; 307:652-659. 


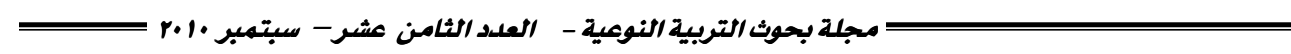

Cefalu, W.T and Hu, F.B. (2004): Role of chromium in human health and in diabetes. Diabetes Care. Nov;27(11):2741-51.

Chapman, D.G.; Gastilla, R. and Campbell, T.A. (1950): Evaluation of protein in food. I. A. Method for the determination of protein efficiency ratio. Can. J. Biochem. Physio. I (37) 679-686.

Coles, E. H (1974): Veterinary Clinical Pathology. Saunders Company, Philadelphia and London.

Crace, C.J., Swenne, I., Kohn, P.G., Strain, A.J and Milner, R.D.G. (1990): Protein-energy malnutrition induces changes in insulin sensitivity. Diabète Métab 16: 484-491.

Davis, C.M and Vincent, J.B (1997): Chromium oligopeptide activates insulin receptor tyrosine kinase activity. Biochemistry; 36:4382-4385.

Dechatelet, L. R., Mc Call, C., E., Mc Phial, L.C. and Johnston, R. B. (1974): Superoxide dismutase activity in leukocytes. J. Clin. Invest., 53: 1197-1201.

Drabkin, D.I. (1949): The standardization of hemoglobin measurements. Am. J. Med. Sci 21 (7): 710.

Fernando, G., Romero,F and Martha, R. (2005): Complementary Therapies for Diabetes: The Case for Chromium, Magnesium, and Antioxidants. Archives of Medical Research 36 250-257.

Fossati, P., Prencipe, L. and Berti, G. (1980): Use of 3,5dichloro-2hydroxybenzene sulfonic acid/4-amlnophenazon chromogenic system in direct enzymatic assay of uric acid in serum and urine. Clin. Chem., 26: 227231.

Franz MJ (1997): Protein: metabolism and effect on blood glucose levels. The Diabetes Educator, 23(6):643-651.

Henry, R. J. (1974): Clinical Chemistry, Principles and techniques 2nd Edition Harper and Row P. 525.

Hoffman, J and Flavo, M. (2004): Protein - which is best? J Sports Sci and Med 3, 118-130.

Hui ,J., Wang, Y., Xiang, J ., Wan ,S., Jing ,N., Tao, W., Yong, J and Zheng,W. F. (2007):Low dose streptozotocin (STZ) combined with high energy intake can effectively induce type 2 diabetes through altering the related gene expression. Asia Pac J Clin Nutr;16 (Suppl 1):412-417.

Jendrassik, L. (1938): Colorimetric determination of bilirubin. Biochem., 97:72-81.

Johansen, J. S., Harris, A. K., Rychly, D.J and Ergul, A. (2005): Oxidative stress and the use of antioxidants in diabetes: linking basic science to clinical practice. Cardiovasc Diabetol; 4:5. 
Kalman, D.S (2003): Chromium picolinate and type 2 diabetes. Am J Clin Nutr;78:192-193.

Kind, P.R and King, E.J. (1954): Estimation of alkaline phosphatase activity by determination of hydrolyzed phenol with aminoantipyrene. J. Clin.Path.7, 322.

Mc Inory, R.A. (1954): A micro heamatocrit for determining the packed cell and hemoglobin concentration on capillary blood. J. Clin. Path. (7): 32.

NRC (1995): National Research council: Nutrient requirements of laboratory animals, fourth revised edition, PP.29-30 National Academy Press. Washington, DC.

Paget, G.E. and Barnes, J .M. (1964): Inter species dosages conversion scheme in evaluation of results and quantitative application in different species toxicity test, 135-165. Academic Press London and NY.

Patton, C . J .and Crouch, S . R .(1977) Anal .Chem ., 49:464-169.

Pedrini, M.T., Levey, A.S and Lau, J. (1996): The effect of dietary protein restriction on the progression of diabetic and non-diabetic renal diseases: a meta-analysis. Ann Intern Med: 124:627-632.

Peschke, E., Ebelt ,H., Bromme,H.J and Peschke,D (2000):Classical and new diabetogens :Comparison of their effects on isolated rat pancreatic islets in vitro .Cell Mol .Life Sci.,57(1):158-164.

Reitman, S and Frankel, S (1957): Determination of glutamate pyruvat transaminase and glutamate oxaloacetate transaminase. Amer. J. Clin. Path., 28:56-63.

Rigalleau, V., Aparicio, M and Gin, H (1998): Effects of low-protein diets on carbohydrate metabolism and energy expenditure. Journal of Renal Nutrition $8175-178$.

Rossetti, L., Rothman, D.L., De Fronzo, R.A and Shulman, G.I (1989): Effect of dietary protein on in vivo insulin action and liver glycogen repletion. American Journal of Physiology 257, 212-219.

Sasaki, T., Matsy, S. and Sonae, A. (1972): Effect of acetic acid concentration on the colour reaction in the O-toluidine boric acid method for blood glucose estimation, Rinsh. Kagaku. , 1: 346-353.

Schmidt-Nielsen, B., Barrett, J. M., Graves, B and Crossley B. (1985): Physiological and morphological responses of the rat kidney to reduced dietary protein. Am J Physiol Renal Physiol 248: F31-F42.

Stocks, J. and Donnandy, J. (1971): The autoxidfation of human red cell lipids induced by hydrogen peroxide. Br. J. Haematol., 20:95-111. 


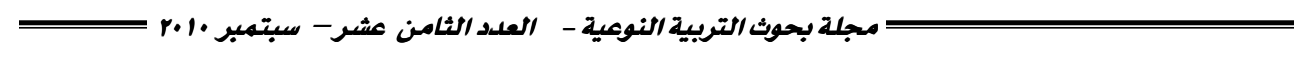

Swenne, I., Crace, C.J and Jansson, L. (1988): Intermittent protein-calorie malnutrition in the young rat causes long-term impairment of the insulin secretory response to glucose in vitro. J Endocrinol 118: 295-302.

Szkudelski, T. (2001): The mechanism of alloxan and streptozotocin action in cells of the rat pancreas. Physiol. Res. 50: 536-546.

Takano, A., Usui ,I., Haruta, T., Kawahara, J., Iwata, M. and Kobayashi, M. (2001): Mammalian target of rapamycin pathway regulates insulin signaling via subcellular redistribution of insulin receptor substratel and integrates nutritional signals and metabolic signals ofinsulin. Molecular and Cellular Biology 21 5050-5062.

Toyoshima, Y., Ohne, Y., Takahashi1, S., Noguchi, T and Kato, H. (2004): Dietary protein deprivation decreases the serine phosphorylation of insulin receptor substrate-1 in rat skeletal muscle. Journal of Molecular Endocrinology 32, 519-531

Tremblay, F and Marette, A. (2001): Amino acid and insulin signaling via the mTOR/p70 S6 kinase pathway. Journal of Biological Chemistry, 276:3805238060 .

Valentine, V., Barone, J.A and Hill, V.C (1998): Gastropathy in patients with diabetes: current concepts and treatment recommendations. Diabetes Spectrum;11(4):248-253.

Wattanakit, K.; Folsom, A.R. and Selvin, E. (2005): Risk factors forperipheral arterial disease incidence in persons with diabetes: Atherosclerosis Risk in Communities (ARIC) Study. Atherosclerosis.180:389-97.

Weichselbaum, T.F (1946): An accurate and rapid method for the determination of protein in small amount of blood serum and plasma .Am .J. Clin .Path. (16):40.

White, M.F (2002): IRS proteins and the common path to diabetes. American Journal of Physiology. 283: 413-422.

Whiteside ,C.L. (2005): Cellular mechanisms and treatment of diabetes vascular complications converge on reactive oxygen species. Curr Hypertens Rep.7:148-54.

Wilson, M.A and Miles ,L.E.M (1977):Radioimmunoassay of insulin in Hand book of Radio immunoassay G .E ,Abraham .ed M. Inc. New York p275.

Ziegler, D. (2005): Type 2 diabetes as an inflammatory cardiovascular disorder. Curr Mol Med; 5:309-22. 
Table (1): Mean values \pm SD of body weight gain, feed intake and feed efficiency ratio (FER) of the experimental rats groups.

\begin{tabular}{|c|c|c|c|c|c|c|c|}
\hline Group & ن̈ & 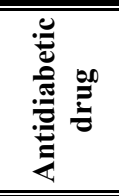 & 音 & 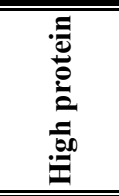 & 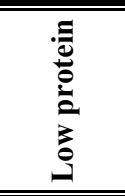 & 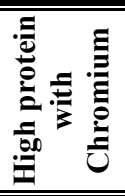 & 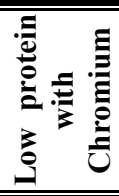 \\
\hline $\begin{array}{c}\text { Initial weight } \\
\text { (g) }\end{array}$ & $\begin{array}{c}190.31 \\
\pm \\
13.61^{\mathrm{a}} \\
\end{array}$ & $\begin{array}{c}191.11 \\
\pm \\
14.22^{a} \\
\end{array}$ & $\begin{array}{c}190.44 \\
\pm \\
13.17^{a} \\
\end{array}$ & $\begin{array}{c}192.35 \pm \\
14.21^{\mathrm{a}}\end{array}$ & $\begin{array}{r}189.99 \pm \\
14.61^{\mathrm{a}}\end{array}$ & $\begin{array}{c}189.59 \pm \\
14.33^{a}\end{array}$ & $\begin{array}{c}190.66 \\
\pm \\
13.77^{a} \\
\end{array}$ \\
\hline $\begin{array}{c}\text { Final } \\
\text { weight }(g)\end{array}$ & $\begin{array}{c}232.45 \\
\pm \\
25.18\end{array}$ & $\begin{array}{c}252.43 \\
\pm \\
33.14^{\mathrm{a}}\end{array}$ & $\begin{array}{c}249.75 \\
\pm \\
3^{2} .85^{\text {a }}\end{array}$ & $\begin{array}{c}255.49 \pm \\
42.91^{\mathrm{a}}\end{array}$ & $\begin{array}{c}216.16 \pm \\
34.71^{a}\end{array}$ & $\begin{array}{c}257.80 \pm \\
43.01^{\mathrm{a}}\end{array}$ & $\begin{array}{c}\mathbf{2 5 0 . 7 7} \\
\pm \\
\text { 38.11 }^{\text {a }}\end{array}$ \\
\hline $\begin{array}{c}\text { Weight gain } \\
\text { (g) }\end{array}$ & $\begin{array}{c}33.14 \\
\pm \\
6.40^{b}\end{array}$ & $\begin{array}{c}61.32 \\
\pm \\
8.33^{a^{* *}}\end{array}$ & $\begin{array}{c}59.31 \\
\pm \\
6^{ \pm .22}{ }^{a^{* *}}\end{array}$ & $\begin{array}{c}63.14 \\
\pm \\
7.10^{a^{* *}}\end{array}$ & $\begin{array}{c}26.17 \\
\pm \\
3.20^{b}\end{array}$ & $\begin{array}{c}68.21 \\
\pm \\
7.30^{a^{* \star}}\end{array}$ & $\begin{array}{c}60.1 \\
1 \pm \\
7.42^{a^{* *}}\end{array}$ \\
\hline $\begin{array}{l}\text { Feed intake } \\
\text { (g/day) }\end{array}$ & $\begin{array}{c}18.65 \\
\pm \\
2.10^{\mathrm{a}}\end{array}$ & $\begin{array}{c}19.11 \\
\pm \\
3.11^{\mathrm{a}}\end{array}$ & $\begin{array}{c}18.95 \\
\pm \\
2.01^{\mathrm{a}}\end{array}$ & $\begin{array}{c}19.35 \\
\pm \\
2.14^{\mathrm{a}}\end{array}$ & $\begin{array}{c}18.30 \\
\pm \\
1.99^{\mathrm{a}}\end{array}$ & $\begin{array}{c}18.30 \\
\pm \\
1.89^{a}\end{array}$ & $\begin{array}{c}18.20 \\
\pm \\
1.29^{a}\end{array}$ \\
\hline FER & $\begin{array}{c}0.029 \\
\pm \\
0.002^{b} \\
\end{array}$ & $\begin{array}{c}0.053 \\
\pm \\
0.0011^{\mathbf{a}^{* *}} \\
\end{array}$ & $\begin{array}{c}0.052 \\
\pm \\
0.005^{a^{* *}} \\
\end{array}$ & $\begin{array}{c}0.054 \\
\pm \\
0.005^{a^{* *}} \\
\end{array}$ & $\begin{array}{c}0.023 \\
\pm \\
0.002^{\text {b }} \\
\end{array}$ & $\begin{array}{c}0.062 \\
\pm \\
0.004^{a^{* *}} \\
\end{array}$ & $\begin{array}{c}0.055 \\
\pm \\
0.0011^{\mathbf{a}^{* *}} \\
\end{array}$ \\
\hline
\end{tabular}

Significant with control group * $\mathbf{P}<0.05 * * \quad \mathbf{P}<0.01 * * * \mathbf{P}<0.001$

Mean values in each raw having different superscript $(a, b, c)$ denote significant difference.

Table (2): Mean values \pm SD of glucose, insulin, hemoglobin and packed cell volume of the experimental rats groups.

\begin{tabular}{|c|c|c|c|c|c|c|c|}
\hline Groups & 苞 & 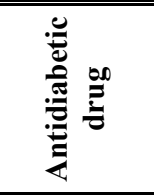 & 当 & 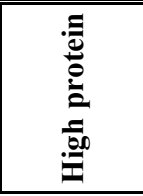 & 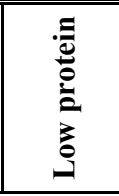 & 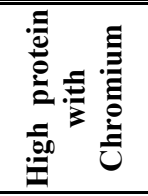 & 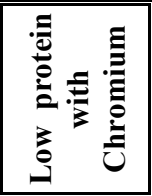 \\
\hline $\begin{array}{l}\text { Glucose } \\
\text { (mg/dl) }\end{array}$ & $\begin{array}{c}301.91 \\
\pm \\
39.71 \mathrm{a} \\
\end{array}$ & $\begin{array}{c}140.17 \\
\pm \\
11.22 \mathrm{c}^{* * *}\end{array}$ & $\begin{array}{c}152.61 \\
\pm \\
13.24 \mathrm{c}^{* * *} \\
\end{array}$ & $\begin{array}{c}155.61 \\
\pm \\
15.41 \mathrm{c}^{* * *} \\
\end{array}$ & $\begin{array}{l}211.41 \pm \\
20.17 b^{*}\end{array}$ & $\begin{array}{c}136.71 \\
\pm \\
11.24 \mathrm{c}^{* * *} \\
\end{array}$ & $\begin{array}{c}161.11 \\
\pm \\
13.76 \mathrm{c}^{* * * *} \\
\end{array}$ \\
\hline $\begin{array}{c}\text { Insulin } \\
(\mu / \mathbf{l})\end{array}$ & $\begin{array}{c}7.31 \\
\pm \\
1.14 \mathrm{~b} \\
\end{array}$ & $\begin{array}{c}13.11 \\
\pm \\
2.15 \mathrm{a}^{* * *} \\
\end{array}$ & $\begin{array}{c}12.01 \\
\pm \\
2.17 \mathrm{a}^{* * *} \\
\end{array}$ & $\begin{array}{c}12.31 \\
\pm \\
7.18 \mathrm{a}^{* * *} \\
\end{array}$ & $\begin{array}{c}8.61 \\
\pm \\
1.03 \mathrm{~b} \\
\end{array}$ & $\begin{array}{c}13.01 \\
\pm \\
2.38 \mathbf{a}^{* * *} \\
\end{array}$ & $\begin{array}{c}10.14 \\
\pm \\
1.41 \mathrm{a}^{* *} \\
\end{array}$ \\
\hline$\underset{(\mathrm{gm} / \mathrm{dl})}{\text { Hemoglobin }}$ & $\begin{array}{c}8.17 \\
\pm \\
0.88 \text { b }\end{array}$ & $\begin{array}{c}12.16 \\
\pm \\
1.14 \mathrm{a}^{* *}\end{array}$ & $\begin{array}{c}11.99 \\
\pm \\
1.87 \mathrm{a}^{* *}\end{array}$ & $\begin{array}{c}12.33 \\
\pm \\
1.41 \mathrm{a}^{* * *} \\
\end{array}$ & $\begin{array}{c}10.33 \\
\pm \\
1.71 \mathrm{a}^{*}\end{array}$ & $\begin{array}{c}12.91 \\
\pm \\
2.14 \mathrm{a}^{* *}\end{array}$ & $\begin{array}{c}11.41 \\
\pm \\
1.33 \mathrm{a}^{* *}\end{array}$ \\
\hline $\begin{array}{c}\text { Packed cell } \\
\text { volume }\end{array}$ & $\begin{array}{c}25.77 \\
\pm \\
3.45 b \\
\end{array}$ & $\begin{array}{c}35.14 \\
\pm \\
4.71 \mathrm{a}^{* *} \\
\end{array}$ & $\begin{array}{c}36.14 \\
\pm \\
4.82 \mathrm{a}^{* *} \\
\end{array}$ & $\begin{array}{c}37.81 \\
\pm \\
3.51 \mathbf{a}^{* *} \\
\end{array}$ & $\begin{array}{c}29.14 \\
\pm \\
3.99 \mathrm{~b} \\
\end{array}$ & $\begin{array}{c}37.41 \\
\pm \\
3.71 \mathrm{a} * * \\
\end{array}$ & $\begin{array}{c}35.93 \\
\pm \\
4.01 \mathbf{a}^{* *} \\
\end{array}$ \\
\hline
\end{tabular}

Significant with control group * $\mathbf{P}<\mathbf{0 . 0 5} * * \quad \mathbf{P}<0.01 * * * \mathbf{P}<0.001$

Mean values in each raw having different superscript $(a, b, c)$ denote significant difference. 


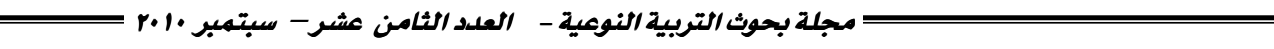

Table (3): Mean values \pm SD of liver GPX, SOD and MDA of the experimental rats groups.

\begin{tabular}{|c|c|c|c|c|c|c|c|}
\hline$p$ & ن̈ & 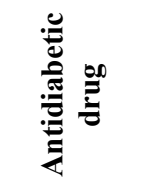 & 音 & 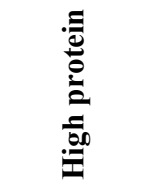 & 章 & 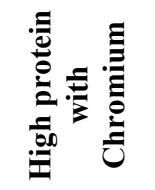 & 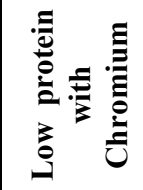 \\
\hline $\begin{array}{c}\text { GPX } \\
\text { (nmol/ mg } \\
\text { tissue) }\end{array}$ & $\begin{array}{c}90.44 \pm \\
5.77 \text { a }\end{array}$ & $\begin{array}{c}130.17 \\
\pm \\
11.28 a^{* * *}\end{array}$ & $\begin{array}{c}135.32 \\
\pm \\
12.46 \mathrm{a}^{* * * *}\end{array}$ & $\begin{array}{c}139.41 \\
\pm \\
13.71 \mathrm{a}^{* * *}\end{array}$ & $\begin{array}{c}68.91 \\
\pm \\
8.16 c^{*}\end{array}$ & $\begin{array}{c}141.31 \\
\pm \\
10.11 a^{* * *}\end{array}$ & $\begin{array}{c}137.14 \\
\pm \\
12.40 \mathrm{a}^{* * *}\end{array}$ \\
\hline $\begin{array}{c}\text { SOD } \\
(\mu / m g \\
\text { protein) } \\
\end{array}$ & $\begin{array}{l}66.99 \pm \\
8.11 \text { b }\end{array}$ & $\begin{array}{c}101.71 \\
\pm \\
10.11 \mathrm{a}^{* *} \\
\end{array}$ & $\begin{array}{c}111.71 \\
\pm \\
11.21 \mathrm{a}^{* * *} \\
\end{array}$ & $\begin{array}{c}103.14 \\
\pm \\
12.41 \mathrm{a}^{* *} \\
\end{array}$ & $\begin{array}{c}65.67 \\
\pm \\
6.71 \mathrm{~b} \\
\end{array}$ & $\begin{array}{c}120.33 \\
\pm \\
11.32 \mathrm{a}^{* * *} \\
\end{array}$ & $\begin{array}{c}109.15 \\
\pm \\
9.99 \mathrm{a}^{* *}\end{array}$ \\
\hline $\begin{array}{c}\text { MDA } \\
\text { (nmol/ } \\
\text { mg tissue) }\end{array}$ & $\begin{array}{c}26.45 \pm \\
2.41 \mathrm{a}\end{array}$ & $\begin{array}{c}15.13 \\
\pm \\
1.33 b^{* *}\end{array}$ & $\begin{array}{c}11.14 \\
\pm \\
1.15 b^{* * *}\end{array}$ & $\begin{array}{c}12.41 \\
\pm \\
1.80 \mathrm{~b}^{* * *}\end{array}$ & $\begin{array}{c}21.98 \\
\pm \\
\text { 3.40a }\end{array}$ & $\begin{array}{c}10.84 \\
\pm \\
1.14 \mathbf{b}^{* * *}\end{array}$ & $\begin{array}{c}13.41 \\
\pm \\
1.91 \mathbf{b}^{* * *}\end{array}$ \\
\hline
\end{tabular}

Significant with control group * $\mathbf{P}<0.05 * * \quad \mathbf{P}<0.01 * * * \mathbf{P}<0.001$

Mean values in each raw having different superscript $(a, b, c)$ denote significant difference.

Table (4): Mean values \pm SD of serum AST, ALT, AP and $\gamma$ GT ratio of the experimental rats groups.

\begin{tabular}{|c|c|c|c|c|c|c|c|}
\hline Groups & 宊 & لم & 声 & 를 & 苞 & ( & 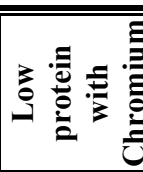 \\
\hline$\underset{(\mu / \mathrm{ml})}{\mathbf{A L T}}$ & $\begin{array}{c}45.22 \\
\pm \\
5.32 \mathrm{a}\end{array}$ & $\begin{array}{c}27.96 \\
\pm \\
5.11 b^{* * *}\end{array}$ & $\begin{array}{c}33.14 \\
\pm \\
4.19 b * *\end{array}$ & $\begin{array}{c}30.21 \\
\pm \\
3.42 \mathrm{~b}^{* *}\end{array}$ & $\begin{array}{c}40.33 \\
\pm \\
5.17 \mathrm{a}\end{array}$ & $\begin{array}{c}28.14 \\
\pm \\
4.22 b^{* * *}\end{array}$ & $\begin{array}{c}32.40 \\
\pm \\
3.61 \mathrm{~b} * *\end{array}$ \\
\hline $\begin{array}{c}\text { AST } \\
(\mu / \mathbf{m l})\end{array}$ & $\begin{array}{c}59.17 \\
\pm \\
6.14 a\end{array}$ & $\begin{array}{c}38.14 \\
\pm \\
4.22 b^{* * *}\end{array}$ & $\begin{array}{c}37.88 \\
\pm \\
3.13 \\
b^{* * *}\end{array}$ & $\begin{array}{c}35.11 \\
\pm \\
3.61 \mathbf{b}^{* * * *}\end{array}$ & $\begin{array}{c}55.71 \\
\pm \\
6.17 \mathbf{a}\end{array}$ & $\begin{array}{c}34.14 \\
\pm \\
3.20 \mathbf{b}^{* * *}\end{array}$ & $\begin{array}{c}39.14 \\
\pm \\
3.17 \mathbf{b}^{* *}\end{array}$ \\
\hline$\underset{(\mu / \mathbf{m l})}{\mathbf{A P}}$ & $\begin{array}{c}99.33 \\
\pm \\
10.13 \mathrm{a}\end{array}$ & $\begin{array}{c}79.33 \\
\pm \\
8.61 b^{*}\end{array}$ & $\begin{array}{c}66.22 \\
\pm \\
7.11 \mathrm{~b} * *\end{array}$ & $\begin{array}{c}65.14 \\
\pm \\
7.14 b^{* *}\end{array}$ & $\begin{array}{c}87.32 \\
\pm \\
9.12 \mathrm{a}\end{array}$ & $\begin{array}{c}61.17 \\
\pm \\
6.01 b^{* *}\end{array}$ & $\begin{array}{c}67.45 \\
\pm \\
7.20 \mathrm{~b}^{* *}\end{array}$ \\
\hline $\begin{array}{l}\gamma \mathbf{G T} \\
(\boldsymbol{\mu} / \mathbf{m l})\end{array}$ & $\begin{array}{c}7.31 \\
\pm \\
1.53 \mathrm{a}\end{array}$ & $\begin{array}{c}4.51 \\
\pm \\
0.88 b^{* * *}\end{array}$ & $\begin{array}{c}5.32 \\
\pm \\
1.11 \mathrm{~b} * *\end{array}$ & $\begin{array}{c}4.99 \\
\pm \\
1.01 b^{* *}\end{array}$ & $\begin{array}{c}6.91 \\
\pm \\
1.31 \mathrm{a}\end{array}$ & $\begin{array}{c}4.81 \\
\pm \\
0.69 b^{* * *}\end{array}$ & $\begin{array}{c}4.71 \\
\pm \\
0.78 b^{* * *}\end{array}$ \\
\hline
\end{tabular}

Significant with control group * $\mathbf{P}<0.05 * * \quad \mathbf{P}<0.01 * * * \mathbf{P}<0.001$

Mean values in each raw having different superscript $(a, b, c)$ denote significant difference. 
Table (5) Mean values \pm SD of serum total protein, albumin, globulin and A/G ratio of the experimental rats groups.

\begin{tabular}{|c|c|c|c|c|c|c|c|}
\hline Groups & ن̈ & 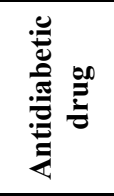 & 音 & 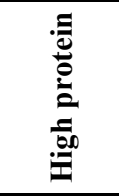 & 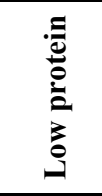 & 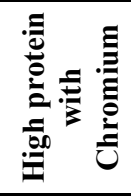 & U \\
\hline $\begin{array}{c}\text { Total protein } \\
\text { (g/dl ) }\end{array}$ & $\begin{array}{c}5.11 \\
\pm \\
1.02 b \\
\end{array}$ & $\begin{array}{c}6.80 \\
\pm \\
1.13 \mathrm{~b} \\
\end{array}$ & $\begin{array}{c}6.81 \\
1.21 \mathrm{~b} \\
\end{array}$ & $\begin{array}{c}7.61 \\
\pm \\
1.30 \mathrm{a}^{*} \\
\end{array}$ & $\begin{array}{c}5.23 \\
\pm \\
1.10 \mathrm{~b} \\
\end{array}$ & $\begin{array}{c}7.78 \\
\pm \\
1.31 a^{*} \\
\end{array}$ & $\begin{array}{c}6.55 \\
1.01 b \\
\end{array}$ \\
\hline$\underset{(g / d l)}{\operatorname{Albumin}(A)}$ & $\begin{array}{c}3.20 \\
\pm \\
0.45 a \\
\end{array}$ & $\begin{array}{c}3.41 \\
\pm \\
0.44 a \\
\end{array}$ & $\begin{array}{c}3.61 \\
\pm \\
0.56 a \\
\end{array}$ & $\begin{array}{c}3.81 \\
0.77 \text { a } \\
\end{array}$ & $\begin{array}{c}3.11 \\
\pm \\
0.60 a \\
\end{array}$ & $\begin{array}{l}3.45 \\
0.55 a \\
\end{array}$ & $\begin{array}{c}3.21 \\
\pm \\
0.33 \mathrm{a} \\
\end{array}$ \\
\hline$\underset{(\mathrm{g} / \mathrm{dl})}{\operatorname{Globulin}(\mathbf{G})}$ & $\begin{array}{c}1.91 \\
\pm \\
0.33 b \\
\end{array}$ & $\begin{array}{c}3.39 \\
\pm \\
0.56 a^{* *} \\
\end{array}$ & $\begin{array}{c}3.20 \\
\pm \\
0.77 \mathbf{a}^{* *} \\
\end{array}$ & $\begin{array}{c}3.80 \\
\pm \\
0.87 \mathbf{a}^{* *} \\
\end{array}$ & $\begin{array}{c}2.12 \\
\pm \\
0.16 a^{*}\end{array}$ & $\begin{array}{c}4.33 \\
\pm \\
0.34 \mathrm{a}^{* * *} \\
\end{array}$ & $\begin{array}{c}3.34 \\
\pm \\
0.35 a^{* * *} \\
\end{array}$ \\
\hline $\mathrm{A} / \mathbf{G}$ ratio & $\begin{array}{c}1.67 \\
\pm \\
0.15 a \\
\end{array}$ & $\begin{array}{c}1.01 \\
\pm \\
0.13 a \\
\end{array}$ & $\begin{array}{c}1.12 \\
\pm \\
0.11 \mathrm{a} \\
\end{array}$ & $\begin{array}{c}1.01 \\
\pm \\
0.03 a \\
\end{array}$ & $\begin{array}{c}1.46 \\
\pm \\
0.21 \text { a } \\
\end{array}$ & $\begin{array}{c}0.79 \\
\pm \\
\text { 0.20b* } \\
\end{array}$ & $\begin{array}{c}0.96 \\
\pm \\
0.11 b^{*} \\
\end{array}$ \\
\hline
\end{tabular}

Significant with control group * $\mathbf{P}<0.05 * * \quad \mathrm{P}<0.01 * * * \mathbf{P}<0.001$

Mean values in each raw having different superscript $(a, b, c)$ denote significant difference.

Table (6) Mean values \pm SD of total bilirubin, creatinine, urea and uric acid of the experimental rats groups.

\begin{tabular}{|c|c|c|c|c|c|c|c|}
\hline Variables & $\stackrel{\overline{0}}{\tilde{E}}$ & 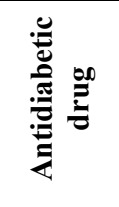 & 咅 & 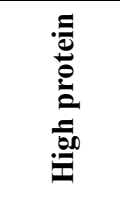 & 苞 & 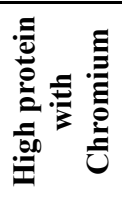 & 吾 \\
\hline $\begin{array}{c}\text { Total bilirubin } \\
(\mathrm{mg} / \mathrm{dl})\end{array}$ & $\begin{array}{c}1.53 \\
\pm \\
0.22 \mathrm{a} \\
\end{array}$ & $\begin{array}{c}1.11 \\
\pm \\
0.02 \text { ab } \\
\end{array}$ & $\begin{array}{c}0.99 \\
\pm \\
0.11 b^{* *}\end{array}$ & $\begin{array}{c}0.98 \\
\pm \\
0.12 b^{* *} \\
\end{array}$ & $\begin{array}{c}1.41 \\
\pm \\
0.18 \text { a } \\
\end{array}$ & $\begin{array}{c}0.97 \\
\pm \\
0.17 b^{* *} \\
\end{array}$ & $\begin{array}{c}0.98 \\
\pm \\
0.33 b^{* *} \\
\end{array}$ \\
\hline$\underset{(\mathrm{mg} / \mathrm{dl})}{\text { Creatinine }}$ & $\begin{array}{c}1.14 \\
0.01 a\end{array}$ & $\begin{array}{c}0.55 \\
\pm \\
0.03 b * *\end{array}$ & $\begin{array}{c}0.65 \\
\pm \\
0.04 b * *\end{array}$ & $\begin{array}{c}0.67 \\
\pm \\
0.01 b^{* *} \\
\end{array}$ & $\begin{array}{c}0.98 \\
\pm \\
0.03 a \\
\end{array}$ & $\begin{array}{c}0.59 \\
\pm \\
0.04 \text { b* }\end{array}$ & $\begin{array}{c}0.71 \\
\pm \\
\text { 0.05b* }\end{array}$ \\
\hline $\begin{array}{c}\text { Urea } \\
(\mathbf{m g} / \mathrm{dl})\end{array}$ & $\begin{array}{c}39.77 \\
\pm \\
4.01 \mathrm{a} \\
\end{array}$ & $\begin{array}{c}25.67 \\
\pm \\
2.31 b^{* *}\end{array}$ & $\begin{array}{c}29.11 \\
\pm \\
2.41 b^{* *}\end{array}$ & $\begin{array}{c}28.31 \\
\pm \\
2.81 b * *\end{array}$ & $\begin{array}{c}27.11 \\
\pm \\
2.77 b^{* *}\end{array}$ & $\begin{array}{c}26.33 \pm \\
4.25 b^{* *}\end{array}$ & $\begin{array}{c}25.76 \pm \\
3.44 a\end{array}$ \\
\hline $\begin{array}{l}\text { Uric acid } \\
(\mathrm{mg} / \mathrm{dl})\end{array}$ & $\begin{array}{c}4.57 \\
\pm \\
1.01 \mathrm{a}\end{array}$ & $\begin{array}{c}3.01 \\
\pm \\
0.99 \mathrm{ab}\end{array}$ & $\begin{array}{c}2.99 \\
\pm \\
0.88 b^{*}\end{array}$ & $\begin{array}{l}3.14 \pm \\
1.11 \mathrm{ab}\end{array}$ & \begin{tabular}{|c|}
2.66 \\
\pm \\
$0.87 b^{*}$
\end{tabular} & $\begin{array}{c}3.11 \\
\pm \\
0.80 \mathrm{ab}\end{array}$ & $\begin{array}{c}2.71 \\
\pm \\
0.21 b^{*}\end{array}$ \\
\hline
\end{tabular}

Significant with control group * $\mathbf{P}<\mathbf{0 . 0 5} * * \quad \mathbf{P}<\mathbf{0 . 0 1} * * * \mathbf{P}<\mathbf{0 . 0 0 1}$

Mean values in each raw having different superscript $(a, b, c)$ denote significant difference. 